\title{
Strengthening the Strategic and Operational Response for Reducing COVID-19 Transmission in Indonesia
}

\author{
Sumengen Sutomo ${ }^{1 *}$, Salord Sagala², Bebi Sutomo ${ }^{3}$, William Liem ${ }^{4}$, Hamzah Al Hamid ${ }^{5}$
}

\author{
${ }^{1}$ Department of Environmental Health, Faculty of Public Health, Universitas Indonesia, Depok, Indonesia \\ 2Data Management Unit, Bangun Indonesia Foundation, Jakarta, Indonesia \\ ${ }^{3}$ Research and Development Unit, Bangun Indonesia Foundation, Jakarta, Indonesia \\ ${ }^{4}$ Northwestern University, Feinberg School of Medicine, Chicago, USA \\ ${ }^{5}$ Department of Occupational Health, Faculty of Public Health, Universitas Indonesia, Depok, Indonesia
}

\begin{abstract}
Indonesia reported the first two cases of COVID-19 from Depok City, West Java, on March 2, 2020. This study aimed to evaluate the strategic response for reducing the COVID-19 transmission which mainly comprised case management, large-scale social restrictions, including micro-scale social restrictions, and the development of drugs and vaccines. The data were collected from the Indonesian Government's official websites and the latest information from March 2020 to May 2021. A logical framework approach and a theory of change were used to describe, evaluate, and strengthen the strategic response. The current strategic response has not reduce the COVID-19 transmission. As of May 30, 2021, 1,879,730 confirmed cases with 101,639 active cases, 1,663,998 recovered, and 50,404 deaths have been reported from 34 provinces. The case management faced a high positive rate and case fatality. The largescale social restrictions have not increased public awareness and behavior practice on the prevention and control. Currently, there is no cure, and the vaccination needs more time to complete. Strengthening the current strategic response needs more testing, contact tracing, better quality treatment, community education for behavior change, and effective vaccination.
\end{abstract}

Keywords: community education for behavior change, COVID-19, strategic response, vaccination

\section{Introduction}

Indonesia reported the first two cases of COVID-19 in Depok city, West Java on March 2, 2020.1 The number of cases has continuously increased, causing high morbidity and mortality from cities and districts. The Government formed Task Forces for COVID-19 Mitigation (Task Force) to support high-level coordination of the national response for the pandemic on March 3, 2020.2 This Force implemented a primary strategic response for physical distancing through mask-wearing at public places, contact tracing, rapid diagnostic test (RDT) or real-time polymerase chain reaction (PCR). They implemented screening and education for self-isolation with medical care at the general, referral, or emergency hospitals. The Ministry of Health $(\mathrm{MoH})$ provided leadership for health system response and adopted its influenza pandemic contingency plan for the COVID-19 response. ${ }^{3}$ The government also declared a regulation on large-scale social restrictions (LSSR)Pembatasan Sosial Berskala Besar (PSBB) in response to the pandemic on March 31 which aimed to prevent the spread

Correspondence*: Sumengen Sutomo, Department of Environmental Health, Faculty of Public Health, University of Indonesia. Kampus Depok Universitas Indonesia Depok Jawa Barat 16424, Indonesia,

E-mail: sumengensutomo@yahoo.com,Phone: +62217863479; +62218307603 of the virus. Local governments were allowed to confine the movement of people or goods in and out of their respective localities, closing public places, schools, restricting public transport, and limiting travel to and from the provinces or regions with the approval of the MoH. ${ }^{4}$

The President of Indonesia, Joko Widodo declared the pandemic as a National disaster and adopted LSSR based on the Health Quarantines Law 2018.5 It was also included as a non-natural disaster by National Disaster Management Office on April 3.6 In line with the 2020 World Health Organization (WHO) strategic preparation and response plan, Indonesian Government, through the $\mathrm{MoH}$ and the National Disaster Management Agency/ Badan Nasional Penanggulangan Bencana (BNPB) responded to the fight against COVID-19 pandemic on April $4 .^{7}$ The outbreak was categorized as a National nonnatural disaster due to its various impacts on humanitarian, public health, education, social, cultural, and economy. A road map with the protocol was issued by the Task Force for accelerating the handling of COVID-19 and the fight against the virus.

Received : June 24, 2021

Accepted : July 25, 2021

Published: July 31, 2021 
The protocol's goal included saving the lives of the population, provision of basic human needs, reducing the impact on socio-economic, and preventing the spread of the virus. It also provided guides on the role and responsibility of the subnational and local leaders, such as data collection, analysis, information management, coordination with stakeholders, public communication, safety or security, LSSR, and stakeholder participation. The strategic response plan of health operation, education, economy, distribution logistic, monitoring, evaluation, and early diagnostic mechanisms were also included in the protocol. ${ }^{8}$

From August 11 to 14, 2020, the World Health Organization Intra-Action Review of Indonesia's Response to COVID-19 conducted a national review of the strategic and operational response. This was assessed based on the nine pillars of the strategic preparedness and plan to identify areas within the public health response that require remediation and improvement. The participants included various representatives units within the Republic of Indonesia $\mathrm{MoH}$, other Government Departments, WHO, and the United Nations agencies who met virtually to review the progress. The results showed the current strategic response was limited coordination and communication between sectors at the national and subnational. It also had limited monitoring indicators, data, and information management, such as delayed reporting or mismatched data and limited utilization of health facilities. ${ }^{9}$ The government, through the Ministry of Internal Affairs, modified the LSRR into micro-scale activities restriction/ Pemberlakuan Pembatasan Kegiatan Masyarakat (PPKM) on January 7, 2021, and enforced on January 11, 2021. The measures, which were implemented in 10 provinces of Java and Bali included limiting activities at workplaces, restaurants, or shopping centers, and fully approving essential sectors activities. On March 23, 2021 PPKM was extended to most Indonesia's provinces. ${ }^{10}$

Over the past 14 months, the implementation of the strategic response has not reduced the pandemic transmission. On May 30, 2021, the number of cases increased to $1,879,730$ confirmed, 101,639 active, $1,663,998$ recovered, and 50,404 deaths. ${ }^{11}$ Several studies were reported on the strategic and operational responsibility of reducing the COVID-19 transmission, which includes reviews on community perception, knowledge, awareness, and behavior practice on its prevention and control. Most of these studies showed the response affected public understanding but limited behavior practice on the prevention and control. Most people ignored mask-wearing in public, maintaining social distance in crowded areas, and avoiding overcrowded public places. Moreover, there are few studies based on impact evaluation of the strategic response. Why has the COVID-19 transmission not reduced? What are the causes? How can the current strategic response be strengthened? This study aims to understand the problem, challenges, proposed solutions, and strengthening the current strategic response for reducing virus transmission. However, the usual implementation of this response has not reduced the transmission but worsen it. Strengthening the current strategic response is required to aid in reducing the disease transmission curve and save more lives.

\section{Method}

A logical framework approach (LFA) was used to describe the current strategic response, while the theory of change (ToC) evaluate the impact, outcome, and outputs for the basis of its strengthening. Data were obtained from the official websites of Indonesian Governments and the latest information from March 2020 to May 2021. The LFA is an analytical or management tool utilized by most multilateral and bilateral aid agencies, international non-governmental organizations, as well as several partner governments for the development program or projects. It is an effective tool when understood and intelligently applied. It also described the current strategic response, including the goal, objective, outputs, indicators, strategy, activities, and risk of achieving the objectives according to the vertical or horizontal logic. 12 The results provided a basis for the response evaluation.

The ToC is a planning method that works backward through a logic model from a statement of the desired impact that the organization plans to achieve through one or more desired outcomes that need to be achieved before the impact can happen to the outputs that should be planned to reach the desired results. The evaluation objective was to identify the problem, causes, effect, and key success factors for strengthening the response. It is a comparison of the actual results with the desired ones, including the impact, outcome, and output before its implementation. ${ }^{13}$ Also, the evaluation results provided the government and its stakeholders, including the community, to continue the fight against COVID-19 and strengthening the current strategic response (Figure 1).

\section{Results \\ Strategic Response}

The overall strategic response was to reduce the pandemic transmission with a target of a reproductive number less than one $(\mathrm{RO}<1.0)$ through case management, LSSR, as well as drugs and vaccines development. Case management, which is a medical care approach, helped to reduce morbidity and mortality by reducing positivity and case fatality rate (CFR) with $<5 \%$ and $<3 \%$ targets respectively. The main activities included testing, contact 


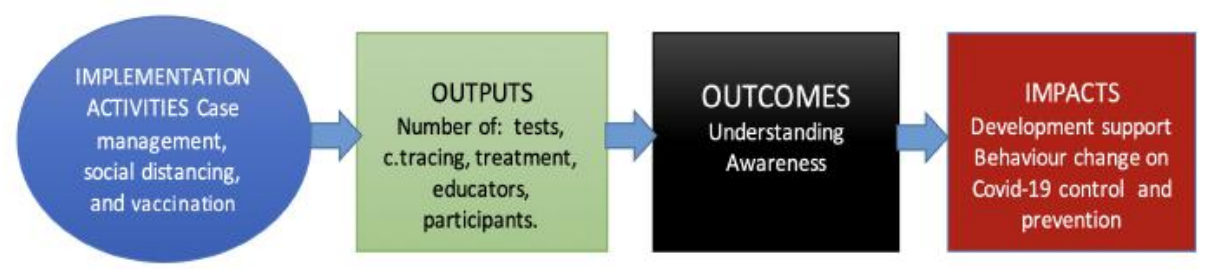

Figure 1. The Logic Model (Source: The North Atlantic Treaty Organization (NATO, 2013)13

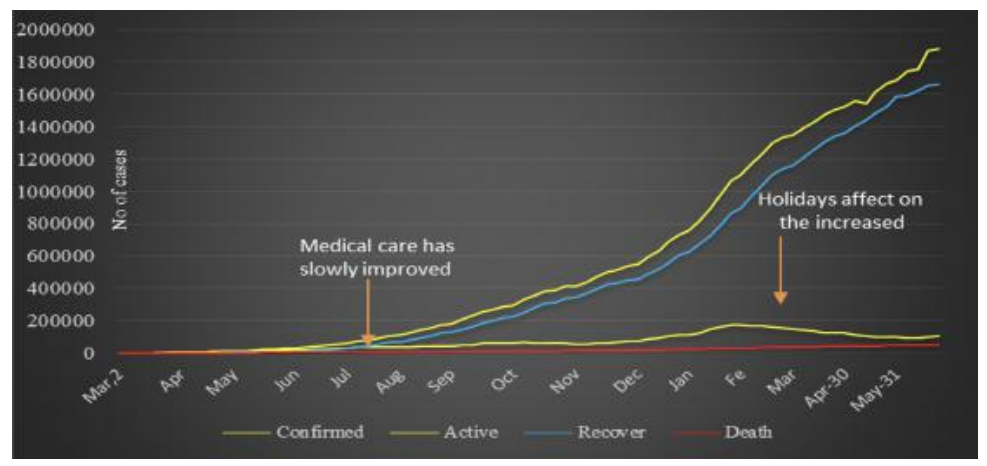

Figure 2. Cases: Confirmed, Active, Recovered, and Deaths

March 2, 2020 - May 31, 2021.11

tracing, isolation, and treatment. A rapid test (RT) for antibody, and antigen, as well as real-time polymerase chain reaction (RT-PCR) provided epidemiological data. The RT antibody was carried out for contact cases of positive patients and those under supervision in areas with no RT-PCR test. In addition, the results were confirmed by RT-PCR. ${ }^{14,15}$

The LSSR was a prevention approach to reduce the COVID-19 transmission through community mobilization and participation. It was also an estimated target to increase public $(>80 \%)$ knowledge, attitude, and behavior practice on prevention and control. The $\mathrm{MoH}$ guided LSSR by suspending activities at schools, workplaces, religious worship, public facilities, social-cultural, and transportation. The population was encouraged to implement mask-wearing, maintaining a minimum 1-1.5 meters distance from others, and regular hand-washing with soap in running water for 20 seconds, which was applied in all provinces, cities, and districts. The government through the Ministry of Internal Affair, modified LSSR to micro-scale activity restrictions as implemented by Java and Bali provinces on January 11, 2021, and subsequently to others regions. ${ }^{16}$

The development of drugs and vaccines was to strengthen both strategies in reducing COVID-19 transmission. This aims to ensure the utilization of medications for treatment and vaccines in public immunity, targeting their availability for prevention. The government through the $\mathrm{MoH}$ and Task Force, partnered with research institutes, private sector, local pharmaceutical companies, and foreign countries developing drugs and vaccines. These include the National Institute of Science, Eijkman Institute for Molecular Biology, PT Bio Farma, National Institute of Health Research and Development, Research Institute of the Universitas Indonesia, Gadjah Mada University, as well as Airlangga University.

\section{Evaluation Strategic Response}

Over the past 14 months, the current strategic response had not reduced the transmission. As of May 31, 2021, the number of cases had increased to $1,927,027$ confirmed, 102,006 active, 1,669,119 recovered, and 50,578 deaths from 34 provinces. The RO was estimated as $>1.0 .17$ (Figure 2). Assessment of case management, LSSR, drugs, and vaccine development explained several causes of the problem.

The case management aid in the reduction of morbidity and mortality by reducing positivity rates and CFR. Based on the strategic response implementation, a weekly average positivity rate was $18.4 \%$, and range of $12.0-35.5 \%$. A weekly average of CFR was $5 \%$, and a range of $3.1-9.5 \%$. The total active and recovered cases were $7.3 \%$, and $91 \%$ respectively in the last week of May 2021. The case management slowly improved in July 2020 but remained a burden on health services at the central and local levels depending on the transmission status. Several government hospitals, such as in Jakarta, West Java, and Central Java Provinces, reported a bed occupancy ratio (BOR) more than $50 \%$ in the last week of May 2021. The BOR in COVID-19 referral hospitals was over $50 \%$ in the province of North Sumatra, Riau Islands, Riau, South Sumatra, Jambi, and Lampung Provinces. After holidays, including New Year and Eid holidays, most hospital 
beds, intensive care unit (ICU) rooms, stock of medicines, and oxygen supplies were needed more for COVID-19 patients. ${ }^{17,18}$ The Amnesty International Indonesia reported that Indonesia is among the countries with the highest number of health workers who have lost their lives to COVID-19, with 188 deaths recorded as of September 2020.19

The LSSR involved the central and local governments, related stakeholders, as well as social media in community mobilization or participation for reducing the virus transmission. The Task Force reported 24\% (range of $15-37 \%$ ) of public perception on LSSR as the prohibition of exit/entry into the area for a certain period. There was closure of airport and seaports, terminals, train stations, and marketplace. The Median-NGO reported 55\% (range $52-60 \%$ ) in the public discipline, compliance to transportation rules, and temporarily worshiping from home. The Task Force, Central Agency for Statistics, and the Median-NGO also reported that public mask-wearing was $60 \%$ when people leave home, $38 \%$ had symptoms, and $42 \%$ were interested in buying. According to UNICEF, the most preventive behavior was the use of masks $(50 \%)$ and hand washing (34\%). Indonesian Red Cross reported that $48.5 \%$ Indonesian thought the COVID-19 was not threatening, and 51.5\% thought it was a threat. ${ }^{20,21}$ A community survey on knowledge, attitude, and practice (KAP) of the adult population was reported by several research teams. Out of the total 640 samples in Yogyakarta (April 2020), 57.1\% had a general knowledge of COVID-19, 44.9\% attitude, and $43.2 \%$ practiced hand-washing, mask-wearing, social distancing, coughing etiquette, and nose touching. ${ }^{22}$ Furthermore, among the 6,249 undergraduate respondents in April-May 2020, 75\% have appropriate knowledge of the virus, $80.4 \%$ have a positive attitude, and $69.9 \%$ practiced health protocol. There was also a significant correlation among knowledge, attitude, and practice on health protocol $(\mathrm{p}<0.000)$, with an $\mathrm{R}$ square of 0.04-0.18.23 A national online survey (August 2020) reported that out of the total 816 sample residents over 18 years, $70 \%$ had appropriate knowledge of the disease, $51.3 \%$ focused on the symptoms, transmission, and prevention, while $40 \%$ had a limitation on the spread. ${ }^{24}$ Micro-scale social restriction was extended and implemented in most provinces, covering more than 14,000 COVID-19 posts in 323 districts of 25 provinces. ${ }^{25}$

The development of drugs and vaccines aims to produce medicines for patient treatment. The MoH identified a substantial amount of therapeutics that could hinder the disease, such as remdesivir, favipiravir, oseltamivir, and lopinavir-ritonavir, which were distributed directly to hospitals as an antiviral agent for quick recovery in moderately ill patients with pneumonia. ${ }^{26}$ The vaccination program proceeded after the Food and Drug Administration granted emergency authorization to Sinovac and AstraZeneca as well as the Indonesian Islamic Clerical Council approval on January 8, 2021.27,28 This program targeted a total of 181.5 million people for 15 months. On May 3, 20,422,518 people had received first and second-dose vaccination where $92.3 \%$, $77.6 \%$, and $18.1 \%$ of the total health workers, public services, and older people were included respectively. ${ }^{29}$ Development of local vaccines Nusantara, Merah Putih with testing tool GeNose C-19 are still in the development process (Table 1).

\section{Discussion \\ Strategic Response}

The current strategic response had not reduced the COVID-19 transmission. In May 2021, the average weekly number of the case was $1,786,487$ confirmed, 96,399 active, 1,625,201 recovered, with 48,813 deaths. The estimation showed that $\mathrm{RO}>1$, but there was insufficient data to calculate Rt. ${ }^{30}$ Over the past months, the incidence rate varied according to the provinces. However, nationally it has never been below zero. The COVID-19 transmission had not been controlled for several reasons such as case management, LSSR, and the development of drugs or vaccines. Meanwhile, the Oxford COVID-19 Government Response Tracker (OxCGRT), using nine indicators including school or workplace closures, as well as travel bans was scored at the Stringency Policy Index (SPI) scale of 60.2 (range 13.9-72.7), and 68.9 (100, strictest) on May 13, 2021.31 Strengthening the current strategic response is required.

\section{Evaluation of Strategic Response Case Management}

Testing, which is updated twice a week, is important for the understanding of the virus spread and the appropriate response. On October 7, 2020, the number of people tested daily was 32,167 , while the suspected cases were 142,213, with a wide gap between both. Over the past 14 months, the average weekly proportion tests of 0.09 per 100,000 population ranged from 0.01 to 0.16 . This gap had continuously existed due to the limited capability of laboratories, personnel, reagents, and cost. The daily average of the test was 100 persons per case, which is less than 1000 recommended by WHO. More testing is required to describe the disease epidemiology. It is also crucial to increase laboratory capacity to ensure the testing of all suspected cases, while the RT antigen could be used to scale up the testing capacity for COVID-19.

The accurate number of tests or contact tracing provided a better quality of epidemiology data and strategic response for reducing the spread. In August 2020, an average number of contact tracing was one suspected case 
Table 1. Summary Evaluation of the Strategic Response

\begin{tabular}{|c|c|c|c|c|c|}
\hline Strategy & Goal & Objective & Target & Achieved & Finding and recommendation \\
\hline Overall strategy & Stop transmission & $\begin{array}{l}\text { Reduced morbidity } \\
\text { Reduced mortality }\end{array}$ & $\mathrm{RO}<1$ & $\mathrm{RO}>1$ & $\begin{array}{l}\text { Transmission had not reduced } \\
\text { Strengthen the strategic response }\end{array}$ \\
\hline $\begin{array}{l}\text { Case management } \\
\text { Testing, tracing, } \\
\text { isolation, treatment }\end{array}$ & $\begin{array}{l}\text { Contributed reduced } \\
\text { morbidity, mortality }\end{array}$ & $\begin{array}{l}\text { Reduced positivity } \\
\text { rate, Reduced CFR }\end{array}$ & $\begin{array}{l}<5 \% \\
<3 \%\end{array}$ & $\begin{array}{l}36.1 \% \text { Feb } 2021 \\
25.3 \% \text { Feb } 2021\end{array}$ & $\begin{array}{l}\text { Limited testing, tracing, surveillance } \\
\text { self-isolation, and treatment, strengthen } \\
\text { the case management }\end{array}$ \\
\hline $\begin{array}{l}\text { LSSR/PSBB } \\
\text { SSSR/PPKM }\end{array}$ & Behavior change & $\begin{array}{l}\text { Public awareness } \\
\text { and behavior practice }\end{array}$ & Most public & $\begin{array}{l}\text { Low KAP: K59\%, } \\
\text { A67.9\%, P64.2\% }\end{array}$ & $\begin{array}{l}\text { Massive information, lack of education } \\
\text { Conduct health education campaign }\end{array}$ \\
\hline $\begin{array}{l}\text { Develop drugs and } \\
\text { vaccine, Local } \\
\text { vaccine }\end{array}$ & $\begin{array}{l}\text { Reduced mortality } \\
\text { Public immunity }\end{array}$ & $\begin{array}{l}\text { Drugs available } \\
\text { Most vaccinated } \\
\text { Increase coverage }\end{array}$ & $\begin{array}{l}\text { Use } 181,5 \\
\mathrm{M} / 15 \mathrm{mo} \\
\text { More coverage }\end{array}$ & $\begin{array}{l}\text { No medicines for the } \\
\text { cure, Low coverage } \\
\text { Incomplete research }\end{array}$ & $\begin{array}{l}\text { Limited treatment, Low coverage } \\
\text { vaccination, Need BPOM Emergency } \\
\text { Use Authorization }\end{array}$ \\
\hline
\end{tabular}

traced by three persons, which was less than the 10-30 recommended by WHO. ${ }^{32}$ With one of the reasons being the limited number of trained frontline health workers from the community health or sub-health centers, village cadres, and volunteers. Also, the low number of testing and limited contact tracing indicated insufficient information on the epidemiological status of COVID-19 as well as the difficulty to decide on the control and prevention of the transmission. More testing and contact tracing should be resolved to provide a better strategic decision for reducing the transmission.

Positivity rate and CFR indicated the transmission status. According to the reported cases from the first week of 2020 to the third week of May 2021, a weekly average positivity rate was $15.0 \%$ (range $9.0-28.8 \%$ ), with a high rate reported in Java-Bali, including DKI Jakarta, Central, and East Java, as well as outside the region such as North Sumatra, East Kalimantan, and Riau. The positivity rate increased during the holiday seasons of Ramadan, Muslims Eid, and New Year. On May 15, it was $13.3 \%$ higher than the WHO recommended $<5 \%$. The case management was yet to control the pandemic spread. In fact, over the past 14 months, the weekly average of CFR was $4.2 \%$, with a range of $2.7-8.2 \%$, compared to the WHO of $<3 \%$ for three weeks which indicated that the COVID-19 was under control. ${ }^{33}$ It also declined from 2.98\% (last week of December 2020) to $2.7 \%$ (last week of March 2021) and increased to $2.76 \%$ in the second week of May 2021. The CFR was higher compared to the global value of $2.3 \%$. Although there was an increase in the recovered cases, COVID-19 remained a burden of the government resources. Most of the reported confirmed cases and deaths based on antigen RT and PCR were included in the test. It was difficult to meet the 90\% surveillance criteria of suspected cases that were isolated and confirmed within 48 hours of symptom onset. At least $80 \%$ of new confirmed cases had their close contacts traced and quarantined within 72 hours of confirmation. There was no benchmark for the number of close contacts that needed to be traced per confirmed case as it depends on how quickly they were isolated to minimize contact with others.

Over the past year, there had been limited health care supplies at the national, province, cities, and district levels, with shortages in laboratory reagents or supplies, personal protective equipment (PPE), as well as critical medications for treatment. Consequently, more frontline health workers were at infection risk due to a lack of protection, which is a significant burden of health services facilities. Since the beginning of the reported cases on March 2, 2020, the Indonesian Medical Association had reported that at least 647 health workers died due to the virus, including 289 doctors, 221 nurses, 84 midwives, 27 dentists, 15 medical laboratory personnel, and 11 pharmacists. It was also estimated that 92 of the workers died per 100,000 cases, the highest in Asia and the fourth-highest fatality rate for health practitioners after Mexico, Egypt, and UK. ${ }^{34}$ Medical care services for noncommunicable diseases such as cancer, diabetes, and children immunization were disrupted due to COVID-19 priority. Hence, protecting all frontline health workers is required to avoid more deaths.

\section{The Large-Scale Social Restriction}

Implementation of LSSR has successfully mobilized media, with various general information being provided daily on the virus, testing, tracing, transmission, prevention, and vaccination. Several acronyms had been introduced, such as 3M, 5M, 3T, PHBS, Food, and Nutrition. The media also provided information integrated into various purposes of communication, education, and advertisement. The news may be dominated by inaccurate information or advertisement, therefore, resulting in confusion and panic.

Disinformation and ignoring scientific beliefs have circulated the public and affected the government's ability to address the pandemic. During the COVID-19 period, the public needed access to information and recommendations from trusted sources like health professionals, scientific experts, experienced patient, and their fam- 
ilies. Conversely, they did not receive what they wanted. Besides the information on mask-wearing, hand-washing, or social distancing, they also needed a correct and accurate explanation of the what, why, and how the virus is transmitted. The public has a different level of education, social status, risks, or vulnerability and also need different messages, communication channel, specific information, as well as education on the primary context of the pandemic causes, treatment, and prevention. It is therefore pertinent that information only is not enough to change behavior practice, but also education, value, attitude, and motivation.

The National Family Planning Board partnered with Population Communication Services (PCS). John Hopkins School of Public Health had successfully increased awareness, attitude, and behavior practice on declining population fertility from TFR 5.6 to 2.6 children per woman (1970-1995). ${ }^{35,36}$ Learning from their lessons is required. Based on the introduction of the various acronym, the $\mathrm{MoH}$, through the Directorate General for Communicable Disease Control and Environmental Health with the public have used more than 50 years for the abbreviation of cleaning, covering, and burying (menguras, menutup, dan mengubur, (3M) as an integrated tool of source reduction for dengue fever/dengue hemorrhagic fever (DF/DHF). ${ }^{37}$ Introducing 3M for COVID19 prevention and control tool, particularly for those living in an endemic DF/DHF, confused the public. Moreover, the additional acronym of 5M may affect more difficult-to-understand limited reading literacy. Although, there was no logical explanation for this except information. Therefore, the introduction of an acronym related to prevention and control should be carefully discussed with the $\mathrm{MoH}$.

Providing only general information is not enough to increase public awareness or behavior practice on COVID-19 prevention and control. The public needs to involve education, attitude change, and motivation. This education includes providing tangible information, personalized messages (unique message for each audience), and interaction with the audience. The information should also be communicated with a great cause, target a specific audience, and interact. Meanwhile, the attitude should be changed through personal value, whether it provides physical, mental, or financial benefits. Furthermore, changing behavior should set expectations and values in learning, sources, and cost. The motivation is a social norm where the audience increases community awareness and behavior practice on health protocols to reduce the number of cases and deaths. Finally, the behavior practice should be based on the usual community norms of the people. ${ }^{38}$ The government and their stakeholders, therefore, need to provide information and include behavior change through public education, value, and attitudes to reduce the COVID-19 transmission.

\section{The Development of Drugs and Vaccines}

To date, there has been no cure for COVID-19. The Food and Drug Administration (FDA US) had granted emergency with authorization to some treatments, including remdesivir, but may provide a modest benefit to patients. Their effectiveness against the virus has not been demonstrated on large-scale, and randomized clinical trials. Also, scientists are currently studying a wide range of other potential treatments, but most are still in the early stages of research. Remdesivir is used in critically ill patients who need oxygen supplementation. It blocks the virus's ability to replicate its genetic material. Meanwhile, Oseltamivir is an antiviral neuraminidase inhibitor used for the treatment and prophylaxis of influenza viruses infection. Recently, Lopinavir and ritonavir are combined to treat HIV, and some studies have tried to stop coronavirus from replicating new cells using Hydroxychloroquine and chloroquine. Convalescent plasma from the blood of recovered flu patients and rich in antibodies, helped the patients fight their illness. ${ }^{39}$

As the Food and Drug Administration (Badan Pengawas Obat dan Makanan/BPOM) granted the emergency authorization to use Sinovac, Sinopharm, and AstraZeneca vaccines with approval from the Indonesian Islamic Clerical Council (Majelis Ulama Indonesia/MUI), sub-sequently, the $\mathrm{MoH}$ began mass vaccination targeting a total of 181.5 million people $(65.7 \%)$ in 34 provinces for 15 months. The first vaccination included 1.3 million health workers and 17.4 million public officials from January-April 2021. The remaining was scheduled for 11 months, from April to March 2022. At the end of April 2021, a total of 12.5 million people had completed Sinovac and AstraZeneca vaccination. On April 30, it was reported that 13 million people had been vaccinated in the provinces. Although there were no significant reported side effects, monitoring of vaccine distribution and side effects should be conducted to guarantee the safe completion of the vaccination program. Development of local drugs in treatment, GeNose C19 for testing, Nusantara and Merah Putih vaccines should subsequently meet the general scientific principle with the outcome receiving the BPOM emergency use authorization. ${ }^{40}$ In addition, approval for the use should be obtained from the MUI.

\section{Conclusion}

The current strategic response for COVID-19 in Indonesia has not reduced its transmission. The main causes include limited response for case management, LSSR, with the development of drugs and vaccines, strengthening is required. The case manage-ment faced challenges of incurability to date, inaccuracy data set, low testing number, limited contact tracing, high 
positivity rate, and CFR. Resolving the critical supply and drug shortages for cases treatment increased the availability and accessibility of RDT or PCR testing, contact tracing, and health services accessibility, quality, or inequality to reduce positivity rate and CFR. The large-scale social restriction, including the microscale social restriction has been implemented by most provinces, cities, and districts partnered with various media. However, most people have not changed their behavior practices on the COVID-19 control and prevention. Providing only general information is not enough for behavior change but community education is also required to give tangible, specific, or unique information for benefit value.

Scientists, health professionals, religious leaders, recovered patients, and their families have a role in combating disinformation, hence, they should actively address the issues. Also, monitoring vaccination programs, including the availability of vaccines, distribution, development of local ones, and the side effect, is required to achieve herd immunity. With the completion of the vaccination program, people are still required to wear masks and maintain social distance. The current national standards based on scientific knowledge of the virus, its spread, possible mutations, treatment, and prevention, research, and development, should be implemented to guide strategic and operational decisions.

\begin{abstract}
Abbreviations
BNPB: Badan Nasional Penanganan Bencana/National Disaster Management Office; BOR: Bed Occupancy Ratio; BPOM: Badan Pengawas Obat dan Makanan/Food and Drug Administration; CFR: Case Fatality Rate; COVID-19: coronavirus disease 2019; HIV: Human Immunodeficiency Virus; ICU: Intensive Care Unit; KAP: knowledge, attitude, practice; LFA: logical framework approach; LSSR/PSBB: large-scale social restrictions; 3M: mask-wearing, hand washing, maintaining social distance; 5M: 3M+avoid overcrowd, and reduce mobility; MoH: Ministry of Health; MUI: Majelis Ulama Indonesia/Indonesian Islamic Clerical Council; NGO: Non-governmental organization; OxCGRT: Oxford COVID-19 Government Response Tracker; PCR: Polymerase chain reaction; PHBS: Perilaku Hidup Bersih dan Sehat/Clean and healthy living behavior; MSSR/PPKM: Microscale social restrictions; R\&D: Research and Development; RDT: Rapid diagnostic test; RO: Reproductive number; Rt: Effective RO; 3T: Testing, Contact Tracing, Treatment; Task Force: Task Force for COVID-19 Mitigation; TFR: Total fertility rate; ToC: Theory of change; WHO: World Health Organization.
\end{abstract}

\section{Ethics Approval and Consent to Participate \\ Not applicable.}

\section{Competing Interest}

The authors have no conflict of interest.

\section{Availability of Data and Materials}

The datasets used and analyzed during the current study are available from the official government document and the internet.

\section{Authors' Contribution}

SS contributed to the designing, conducting, as well as the writing of the article and also assisted with the data collection, review, and described the strategic response. BS contributed to analysis data interpretation. WL contributed to the designing and oversight of the report, while $\mathrm{HH}$ assisted with the overall review of the data.

\section{Acknowledgment}

The authors are grateful to Sri Wrinarti, Gelant Sanjaya, Santi Lisana, Bagus Pramudito, Fenti Susanti, and Kamal Zaman for their support, technical review, and discussion of the COVID-19 transmission national issues.

\section{References}

1. World Health Organization. Coronavirus Disease 2019 (COVID-19) world health: situation report; 2020.

2. JDIH BPK Republik Indonesia. Keputusan Presiden (KEPPRES) tentang gugus tugas percepatan penanganan corona virus disease 2019 (COVID-19); 2020.

3. Wibowo A. Arahan dan strategi ketua gugus tugas penanganan COVID-19 untuk Pemerintah Daerah. Jakarta: Humas BNPB; 2020.

4. Deputi Bidang Hukum dan Perundang-Undangan. Kementerian Hukum dan Perundangan Sekretariat Negara RI. Peraturan Pemerintah RI nomor 21 tahun 2020 tentang pembatasan sosial berskala besar dalam rangka percepatan penanganan corona virus dis-eases 2019 (COVID-19); 2020.

5. Office of Assistant to Deputy Cabinet Secretary for State Documents \& Translation. Press statement of President of the Republic of Indonesia on a social security program to address the impacts of COVID-19 pandemic: Bogor; 2020.

6. Gugus Tugas Percepatan Penanganan COVID-19. Protokol percepatan penanganan pandemi COVID-19 (Coronavirus disease 2019); 2020.

7. World Health Organization. 2019 Novel Coronavirus (2019 nCoV): strategic preparedness and response plan. Geneva, Switzerland; 2020.

8. Badan Nasional Penanggulangan Bencana. Sosialisasi protokol kesehatan wajib jadi program prioritas daerah. Pusat Data Informasi dan Komunikasi Kebencanaan BNPB; 2020.

9. World Health Organization. Intra-action review of Indonesia's response to COVID-19: summary report. Jakarta; 2021.

10. Office of Assistant to Deputy Cabinet Secretary for State Documents \& Translation. Gov't extends micro-scale activity restrictions until March 22 2021. Jakarta: Cabinet Secretariat of the Republic of Indonesia; 2021.

11. Komite Penanganan COVID-19 dan Pemulihan Ekonomi Nasional (KPC dan PEN). Satuan gugus tugas COVID-19. Peta sebaran COVID-19. Jakarta: Satuan Tugas Penanganan COVID-19; 2021.

12. United States Agency for International Development. Technical note: the logical framework; 2012.

13. North Atlantic Treaty Organization. A framework for the strategic planning \& evaluation of public diplomacy; 2013. 
14. Commission for Case Manager Certification. Introduction to the case management body of knowledge; 2021.

15. Ritchie, et al. Statistics and research coronavirus (COVID-19); 2021

16. Office of Assistant to Deputy Cabinet Secretary for State Documents \& Translation. Gov't extends micro-scale restrictions policy; 2020.

17. Desai R. Understanding R naught: current events in health and medicine. Khan Academy; 2014.

18. World Health Organization. Coronavirus disease 2019 (COVID-19) world health: situation report-54; 2021.

19. Amnesty International Indonesia. Unprotected, overworked, ailing Indonesian health workers face an avalanche of COVID-19 cases; 2020.

20. Suara Komunitas. The community's perception of COVID-19. ALNAP; 2020.

21. Badan Pusat Statistik. Perilaku masyarakat di masa pandemi COVID19. Jakarta: BPS RI; 2020.

22. Kristina SA, Annisa M, Ihsan M. Gaps in the public's awareness and protective practices during a pivotal time of COVID-19 pandemic: a survey from Indonesia. Yogyakarta: University of Gadjah Mada; 2020.

23. Saefi M, et al. Survey data of COVID-19-related knowledge, attitude, and practices among Indonesian undergraduate students. Data Brief; 2020.

24. Sulistyawati, et al. Knowledge, attitudes, practices and information needs during the COVID-19 pandemic in Indonesia. Risk Manag Health Policy. 2021; 14: 163-175.

25. Office of Assistant to Deputy Cabinet Secretary for State Documents \& Translation. Gov't to extend micro-scale restrictions in 25 Provinces. April 212021.

26. Asia-Africa Anadolu Agency. Indonesia to import therapeutic drugs amid record COVID-19 surge; 2021.

27. Office of Assistant to Deputy Cabinet Secretary for State Documents \& Translation. BPOM issues EUA for Sinovac COVID-19 vaccine; 2021.
28. Hariyadi, M. Indonesian ulema say AstraZeneca vaccine is 'lawful' in case of emergency. AsiaNews; 2021.

29. Sutarsa I Ny. East Asia Forum Economics, Politics and Public Policy in East Asia and the Pacific. Indonesia's vaccine campaign hits speed bumps; 2021.

30. Royal Society. Reproduction number (R) and growth rate (r) of the COVID-19 epidemic in the UK: methods of estimation, data sources, causes of heterogeneity, and use as a guide in policy formulation; 2020.

31. Blavatnik School of Government, University of Oxford. COVID-19 government response tracker (xCGRT); 2021.

32. Ritchie H, et al. Coronavirus (COVID-19) testing. Published Online at OurWorldInData.org; 2020.

33. Hasell J. Testing early, testing late: four countries' approaches to COVID-19 testing compared. Published Online at OurWorldInData.org; 2020.

34. Widadio NA. Coronavirus kills 647 health workers in Indonesia. Jakarta: Anadolu Agency; 2021.

35. National Family Planning Coordination Board (BKKBN). The success of the Indonesia family planning program is still a world reference; 2017.

36. Health Communication Partnership. Steps in strategic communications; 2003.

37. Kementerian Kesehatan Republik Indonesia. Kesiapsiagaan menghadapi infeksi COVID-19, kendalikan DBD dengan PSN 3M Plus; 2016.

38. Cross J. Three myths of behavior change - what you think you know that you don't; 2013.

39. Wu KJ, Zimmer C, Corum J. coronavirus drug and treatment tracker. The New York Times; 2021.

40. University of Stellenbosch Business School. Why publication in an academic journal matters; 2018. 